\title{
VELIKA POLJIČKA LJEKARUŠA (BRATULIĆEVA LJEKARUŠA)
}

\section{GREAT FOLK MEDICINE BOOK FROM POLJICA (BRATULIC'S FOLK MEDICINE BOOK)}

\author{
Nikola Kujundžić*
}

\begin{abstract}
SAŽETAK
U ovom radu prikazana je ljekaruša napisana u i8. stoljeću na području Poljica. Budući da se sačuvala i nalazi se u vlasništvu Josipa Bratulića, filologa, povjesničara književnosti i bibliofila, autor ovog rada predlaže da se nazove Velika poljička (Bratulićeva) ljekaruša. Ljekaruša se sastoji od 288 nepaginiranih stranica ispisanih rukom istog autora, crnom tintom. Napisana je latinicom hrvatskim jezikom. Dobro je očuvana, tek manji dio je nečitak. Sadrži više od IIoo recepata i po tome se može ubrojiti među velike ljekaruše. Većina recepata odnosi se na liječenje ljudi, manji dio na liječenje životinja, a samo nekoliko recepata su savjeti za domaćinstvo. Bogatstvom sadržaja izričaja i naputaka za liječenje nadovezuje se na niz sličnih rukopisa koji čine dragocjeni segment hrvatske medicinske, farmaceutske $i$ kulturne baštine.
\end{abstract}

Ključne riječi: Bratulićeva ljekaruša, zbirke recepata, narodna medicina, I8. stoljeće, Poljica, Hrvatska

\section{UvoD}

Zbirke propisa za izradu ljekovitih pripravaka i načina njihove uporabe pri liječenju pojedinih bolesti koje se u literaturi nalaze pod imenom ljekaruše, pisale su se na hrvatskim prostorima od I4. do 20. stoljeća. Recepti u ljekarušama pretežito se odnose na liječenje bolesti ljudi (najčešće su to simptomi,

Adresa za dopisivanje: Nikola Kujundžić, Ante Topića Mimare 23, 10090 Zagreb, Hrvatska. E-pošta:nkujundzic1@gmail.com. 
tegobe i različita zdravstvena stanja), a u manjoj mjeri i domaćih životinja. U pojedinim ljekarušama mogu se naći i različiti savjeti korisni u domaćinstvu (preporuke za prehranu, čuvanje hrane, dezinfekcija, higijena). U receptima su se sublimirala iskustva u liječenju koja su se tijekom povijesti sakupljala najprije usmenom predajom, a pojavom pismenosti ta su se iskustva i postupci zapisivali u obliku recepata. Zato su u ljekarušama vidljivi tragovi svih faza razvoja medicine/farmacije od antičke grčke i rimske te arapske medicine, koje se miješaju s tisućugodišnjim iskustvima domaće etnomedicine i prakse u izradi lijekova. ${ }^{1}$ Samo mali broj ljekaruša izišao je u tiskanom obliku. Dvije su objavljene u Veneciji krajem I8. stoljeća ${ }^{2,3}$, a jedna polovicom I9. stoljeća ${ }^{4}$. Sve druge poznate ljekaruše su rukopisi koji su služili kao svojevrsni medicinski priručnici ${ }^{5,6}$. Pisane su najčešće latinicom ili hrvatskom ćirilicom, ali i glagoljicom i goticom na različitim jezicima: hrvatskom, talijanskom, latinskom i njemačkom. Ljekaruše su vrijedni otisci vremena u kojem su nastajale. Iz njih se može saznati o pismenosti, jeziku, običajima, liječenju, vjerovanjima, životnim prilikama i dr. pa izazivaju zanimanje različitih stručnjaka.

Unatoč velikom napretku medicine i farmacije, zanimanje za tradicionalne lijekove i dalje je veliko, štoviše u posljednje vrijeme raste? a brojna ljekovita sredstva opisana u ljekarušama i danas su dostupna na farmaceutskom tržištu.

Veće zanimanje znanstvenika za sakupljanje narodnog blaga, pa tako i za ljekaruše, pojavilo se početkom 20. stoljeća, nakon što je i897. Antun Radić objavio svoje djelo Osnove za sabiranje i proučavanje građe o narodnom životu ${ }^{8}$.

1 Kujundžić, Nikola (2014). Velika sinjska ljekaruša, Zagreb; Hrvatska akademija znanosti i umjetnosti, Matica hrvatska, Sveučilište u Zagrebu - Farmaceutsko-biokemijski fakultet.

2 Vladimirović, Luka (1775). Likarije priprostite, Mleci; (Pretisak, transkripcija i prilozi. Priredio: Devetak Z. Knjižnica zbornika "Kačić", br. 34, Split - Zaostrog: Franjevačka provincija Presv. Otkupitelja, 1999).

3 Bartulović, Petar (1779). Razlicite likarie, Venecija.

4 Lalić, Josip (1849). Otvoranje domaćeg lečstva za ljude i marvu. Zagreb; Tiskom bratje Županah 1849.

5 Šušnić-Fliker, Zdenka (1986), Narodne ljekaruše iz Hrvatske nastale u XVII i XVIII stoljeću, Farmaceutski glasnik, 42 (12), 367.

6 Brenko, Aida; Dugac, Željko; Randić, Mirjana (2001). Narodna medicina. Zagreb; Etnografski muzej.

7 Barnes, Joanne; Anderson, Linda A.; Phillipson, David J. (2002). Herbal Medicines, A guide for healthcare professionals, $2^{\text {nd }}$ Ed., London; Pharmaceutical Press.

8 Radić, Antun (1897). Osnova za sabiranje i proučavanje građe o narodnom životu, Zagreb; Zbornik za narodni život i običaje Južnih Slavena. Knjiga 2. 
U to vrijeme objavljeno je više radova o ljekarušama. ${ }^{9-14}$ Poslije se to zanimanje smanjilo tako da se duže vrijeme, od početka Prvoga svjetskog rata do devedesetih godina 20. stoljeća, ljekaruše objavljuju tek povremeno. ${ }^{15-22}$ Od uspostave neovisne Rebulike Hrvatske zanimanje za proučavanje ljekaruša naglo je poraslo. Tako su u izdanju HAZU-a objavljene četiri knjige u kojima je opisano šest ljekaruša, ${ }^{23-25}$ a u posebnim izdanjima časopisa Acta medico-historica adriatica dvije knjige u kojima su opisane dvije ljekaruše. ${ }^{26,27}$ U tih su šest knjiga uz transkripte odnosno transliteracije objavljeni i faksimili originalnih rukopisa. To nam se čini posebno važnim jer se na taj način

9 Medić, Mojo (1904), Tri ljekaruše, Glasnik zemaljskog muzeja BiH, 16, 1 i 195.

10 Medić, Mojo (1909), Četiri ljekaruše, Zbornik za narodni život i običaje Južnih Slavena, 14 (2), 168.

11 Gundrum-Oriovčanin, Fran (1909), Luićeva ljekaruša, Zbornik za narodni život $i$ običaje Južnih Slavena, 14 (1), 55.

12 Strohal, Rudolf (1910), Folkloristički prilozi iz starije hrvatske knjige. I. Različiti zapisi i čaranja. (Glagoljski hrv. Spomenik iz 15. vijeka). Zbornik za narodni život i običaje južnih Slavena, 15, 121.

13 Milčetić, Ivan (1913), Stari glagoljski egzorcizmi, recepti i zapisi, Vjesnik Staroslavenske akademije, 13(1), 61.

14 Boranić, Dragutin (1915), Đakovačka ljekaruša, Zbornik za narodni život $i$ običaje Južnih Slavena, 20 (1), 142.

15 Stošić, Krsto (1934), Šibenska ljekaruša, Liječnički vjesnik, 7, 189.

16 Stojković, Marijan (1938), Dvije hrvatske ljekaruše iz Dalmacije, Zbornik za narodni život $i$ običaje Južnih Slavena, 31 (2), 201.

17 Berić, Dušan (1957), "Likarice" don Mikule Bobetića iz druge polovine XVII vijeka. Narodno zdravlje, 13, 386.

18 Tartalja, Hrvoje (1964), Ljekaruša iz Mađareva, Zbornik za narodni život $i$ običaje Južnih Slavena, 489.

19 Filipović-Fabijanić, Radmila (1971), “Domaći ljekar” iz 1868, godine sa Širokog Brijega, Glasnik Zemaljskog muzeja Bosne i Hercegovine; Etnologija; Nova serija, 26.

20 Ujević, Ante (1973), Ljekaruša fra Šimuna Gudelja Imoćanina, Kačić, 5, 121.

21 Vrčić, Vjeko (1984), Ljekaruše biskupa fra Paške Vujčića, Nova et vetera, 1-2, 139.

22 Belicza, Biserka (1986), Pučka medicina u okolici Imotskoga prema zapisima fra Silvestra Kutleše, Kačić, 18, 78.

23 Poljak, Željko (2009). Karlobaške ljekaruše iz 1603. i 1707. godine, Faksimil i obrada, Rasprave i građa za povijest znanosti, Knjiga 9, Razred za medicinske znanosti, Svezak 5, Zagreb, HAZU.; Vidi još: Kujundžić, Nikola (2014). Velika sinjska ljekaruša.

24 Nazor, Ante (2010). Knjige od likarije. Faksimil i obrada dviju ljekaruša pisanih hrvatskom ćirilicom. Rasprave i građa za povijest znanosti, Knjiga 10. Razred za medicinske znanosti, Svezak 6. Zagreb, HAZU.

25 Kujundžić, Nikola (2017), Ljekaruša fra Mirka Šestića. Obrada, transkript i faksimil, u: Rasprave i građa za povijest znanosti. Narodna medicina - izvori i straživanja; Zagreb, HAZU, (17), 6.

26 Kujundžić, Nikola; Škrobonja, Ante; Glibota Milan; Gašparac Petra (2011). Libar od likarij don Petra Kaštelana. Biblioteka AMHA, Prilozi povijesti zdravstvene kulture, Knjiga 7, Rijeka; Hrvatsko znanstveno društvo za povijest zdravstvene kulture i Medicinski fakultet Sveučilišta u Rijeci.

27 Zrnić, Lidija (2014). Jurićeva likaruša, Biblioteka AMHA, Prilozi povijesti zdravstvene kulture, Knjiga 10, Rijeka; Hrvatsko znanstveno društvo za povijest zdravstvene kulture i Medicinski fakultet Sveučilišta u Rijeci. 
čuvaju ti rijetki i važni tekstovi i čine dostupnima znanstvenicima za daljnje proučavanje. Osim spomenutih knjiga, u znanstvenim i stručnim časopisima $\mathrm{u}$ istom je razdoblju objavljeno desetak tekstova o ljekarušama. ${ }^{28-37}$

U državnim, samostanskim i privatnim arhivima postoji još znatan broj neopisanih ljekaruša. Pohranjene su često u uvjetima koji pogoduju njihovu propadanju. Zbog toga bi ih trebalo zaštititi i opisati kako bi ovaj važni dio hrvatske kulturne baštine dobio svoje zasluženo mjesto.

Najviše su ljekaruša napisali svećenici. U literaturi se nazivaju prema imenima autora: ljekaruše fra Šimuna Gudelja ${ }^{38}$, fra Jakova Bartulovića ${ }^{39}$, fra Paške Vujčića ${ }^{40}$, fra Karla Grančića ${ }^{41}$, don Petra Kaštelana ${ }^{42}$, don Mikule Bobetića ${ }^{43}$ i dr., ali ih katkad pišu i svjetovne osobe (dotur Markovićc ${ }^{44}$ ). Ako autor nije poznat, što nije rijetkost jer često nedostaju prve stranice, nazivaju se prema mjestu u kojem su nađene ili nastale (Šibenska ${ }^{45}$, Sinjska ${ }^{46}$,

28 Kujundžić, Nikola; Zorc, Marina; Glibota, Milan; Kujundžić, Milan (2004); Ljekaruša fra Jakova Bartulovića, Farmaceutski glasnik, 60 (11), 541.

29 Kujundžić, Nikola; Škrobonja, Ante; Tomić, Tomislava (2006), Plehanska ljekaruša „Zbirka lijekova sa zbirkom ljekovitih trava i uputom za pravit meleme i murćefe, Acta medhist Adriat, 4 (1), 37.

30 Kujundžić, Nikola; Matasić, Vlatka; Glibota, Milan (2003), Ljekaruša fra Karla (Dragutina) Grančića, Farmaceutski glasnik, 59 (7-8), 321.

31 Kujundžić, Nikola; Glibota, Milan; Bival, Maja (2006), Ljekaruša fra Dobroslava Božića, Farmaceutski glasnik, 62 (12), 669.

32 Dürrigl, Marija A.; Fatović-Ferenčić, Stella (1999). Marginallia miscellanea medica in Croatian Glagolitic Monuments: a Model for Interdisciplinary Investigations, Viator, (30), 383.

33 Dürrigl, Marija A.; Fatović-Ferenčić, Stella (1995). Odabrani zapisi protiv bolesti u hrvatskim glagoljskim rukopisima. Liječnički vjesnik, (117), 152.

34 Dürrigl, Marija A.; Fatović-Ferenčić, Stella (1997), Marginalia medica croatico-glagolitica, Liječnički vjesnik, (119), 174.

35 Dürrigl, Marija A.; Fatović-Ferenčić, Stella (2009), Hrvatske ljekaruše između medicine, vjere i književnosti, u: Rasprave i građa za povijest znanosti, Knjiga 5, Razred za medicinske znanosti, Svezak 5, Zagreb, HAZU, 141.

36 Poljak, Željko (1999), Odiseja jedne ljekaruše, Liječničke novine, (146), 42.

37 Rimac-Lasić, Smilja; Škrobonja, Ante (1992), Tri ljekaruše imotskih franjevaca, Acta Fac ned flum, 17 (3-4), 183.

38 Ujević, Ante (1973), 121.

39 Kujundžić, Nikola et al. (2004), 541.

40 Vrčić, Vjeko (1984), 139.

41 Kujundžić, Nikola et al. (2003), 321.

42 Kujundžić, Nikola et al. (2011), Libar od likarij

43 Berić, Dušan (1957), 386.

44 Medić, Mojo (1909), Četvrta ljekaruša, Zbornik za narodni život i običaje Južnih Slavena, 14 (2), 253.

45 Stošić, Krsto (1934), 189.

46 Kujundžić, Nikola (2014). Velika sinjska ljekaruša. 
Karlobaška ${ }^{47}$, Đakovačka ${ }^{48}$ i dr.). Katkad se ljekaruše nazivaju prema autoru koji ih je obradio ili sačuvao (Strohalova ljekaruša ${ }^{49}$ ).

\section{Opis Velike poljičKe (Bratulićeve) LJekaruše}

Velika poljička (Bratulićeva) ljekaruša pisana je najvjerojatnije u i8. stoljeću na području Poljica. Poljica su Požarevačkim mirom I7I8., nakon više od dvjesto godina osmanske okupacije, došla pod vlast Mlečana i ostala pod njihovom vlašću do pada Mletačke Republike i797. godine. Bez obzira na mijenjanje moćnih sila koje su Poljicima vladale i gotovo neprekidno višestoljetno ratno stanje na ovome pograničnom području, Poljica su zadržala veći ili manji stupanj autonomije odnosno samouprave koju talijanski prirodoznanac i putopisac A. Fortis u svom poznatom djelu Put po Dalmaciji (I774.) naziva republikom ${ }^{50}$. Poljica su imala svoj zakonik (statut), svoju upravu koja se birala svake godine te pečat i zastavu ${ }^{51}$.

Administrativna posebnost i organiziranost odražavala se u svim sferama seoskog života. Za vrijeme turske okupacije zdravstvene prilike u Poljicima bile su izrazito teške. Frano Ivanišević u svom djelu POLJICA Narodni život $i$ običaji ${ }^{52}$ (prvo izdanje objavljeno I906.) piše da narod razlikuje likara koji liči naraunim načinom, od čarounika, koji diže čare i čini zapise proti bolestin... Likari i likarice, kako ih narod naziva u šali, a Ivanišević još seoski likar i domaći likar, postoje u svakom plemenu i liječe ponajviše travama. I u i8. stoljeću, za vrijeme mletačke vlasti, žitelji Poljica u liječenju su se oslanjali uglavnom na narodne liječnike. Školovani su liječnici bili malobrojni i djelovali su u okolnim gradovima (Split, Sinj, Omiš), bili su zbog prometne nepovezanosti daleko i bili su skupi. Osim toga, narod im nije vjerovao jer su uglavnom bili stranci. Tako F. Petter I856. piše da je obični puk bio zakleti neprijatelj liječnika i ljekarnika i da nije vjerovao u njihova znanja ${ }^{53}$. Nekoliko objavljenih ljekaruša koje su nastale u Poljicima ${ }^{54-56}$ pisane su hrvatskom ćirilicom u drugoj

47 Poljak, Željko (2009). Karlobaške ljekaruše.

48 Boranić, Dragutin (1915), 142.

49 Strohal, Rudolf (1910), 121.

50 Fortis, Alberto (1984). Put po Dalmaciji, Zagreb; Globus, 205.

51 Nazor, Ante Ml. (2010), Povijesni osvrt na Poljica, u: Knjige od likarije. Rasprave i građa za povijest znanosti. Knjiga 10. Zagreb; HAZU, 223.

52 Ivanišević, Frano (2006). Poljica, Narodni život i običaji, Priko; Društvo Poljičana „Sveti Jure", 296.

53 Petter, Franz (1856). Dalmatien in seinen verschiedenen Bezichungen. Wien; Druck von Leopold Sommer, 198.

54 Medić, Mojo (1909), 168.

55 Nazor, Ante (2010). Knjige od likarije.

56 Kujundžić, Nikola et al. (2011), Libar od likarij. 
polovici I8. stoljeća. U njima je nađen određen broj istih ili sličnih recepata. Bilo bi ih korisno, zajedno s Velikom poljičkom (Bratulićevom) ljekarušom, obuhvatiti komparativnom studijom. Na prostoru bivše Jugoslavije tiskane su tri bibliografije s popisima ljekaruša. Sve tri su nepotpune. U nijednoj se ne spominje ovaj rukopis. ${ }^{57-59} \mathrm{U}$ receptu br. 944 autor govori u prvom licu: ovim sam melemom ozdravio vise od dvi igliade rana smartni i svachi drugli nacoiesam godir po zvan - nisam ni na cacovu ranu mechio nicad drugoga, što jasno upućuje na to da se ljekarušom koristio kao priručnikom.

Rukopis ove ljekaruše nalazi se u vlasništvu filologa, povjesničara književnosti i bibliofila akademika Josipa Bratulića koji ju je pronašao, tvrdo ukoričio i sačuvao u svojoj velikoj kolekciji starih knjiga.

Kao što je čest slučaj kod starih rukopisa, i ovdje nedostaje nepoznat broj početnih i završnih stranica. Ljekaruše se u literaturi nazivaju po autorima, mjestu u kojemu su nastale ili pronađene, vlasniku ili autoru koji ih je opisao. U ovom rukopisu nije naveden autor, a na margini 220. stranice napisano je Poglica.. i nečitak nadnevak. Međutim, budući da je objavljeno nekoliko poljičkih ljekaruša, ${ }^{60,61}$ čini nam se prikladnim ovu ljekarušu nazvati Velika poljička (Bratulićeva) ljekaruša. To će jasno upućivati na to o kojem je rukopisu riječ i gdje se nalazi. Ljekaruša se sastoji od 288 nepaginiranih stranica (slika r.), ispisanih po svemu sudeći rukom istog autora, crnom tintom. Dobro je očuvana, a mali je dio nečitak. Sadrži II4I recept i po tome se može ubrojiti među velike ljekaruše. Većina recepata odnosi se na liječenje ljudi, a manji dio na liječenje životinja. Samo nekoliko recepata su savjeti za domaćinstvo. Pojedine skupine recepata koje se bave liječenjem određene bolesti imaju odgovarajuće naslove. Primjerice: od otrova licarie; cogabi zmia uila licarie; od tiscgnie licarie; od xutinice aliti zlatignie; od fibre i od groznice licarie.

JEZIK

Velika poljička (Bratulićeva) ljekaruša napisana je latinicom hrvatskim jezikom. U pojedinim poglavljima naknadno su na vrhovima stranica hrvatskom ćirilicom ispisani nazivi bolesti kojima se dotično poglavlje bavi. Očito

57 Elazar, Samuel; Omanić, Ajnija (1984). Bibliografija medicinskih djela u SR BiH do 1895, Beograd-Zagreb; Medicinska knjiga.

58 Grmek, Mirko D. (1963). Rukovet starih medicinskih, matematičko-fizičkih, astronomskih, kemijskih i prirodoslownih rukopisa sačuvanih u Hrvatskoj i Sloveniji. Rasprave i građa za povijest nauka. Knjiga I, Zagreb; JAZU, 259.

59 Romano, Jaša (1973). Jugoslovenska bibliografija lekaruša i narodnih medicinskih rukopisa. Beograd; Naučno društvo za istoriju zdravstvene kulture Jugoslavije.

60 Nazor, Ante (2010), Knjige od likarije.

${ }^{61}$ Kujundžić, Nikola et al. (2011), Libar od likarij. 


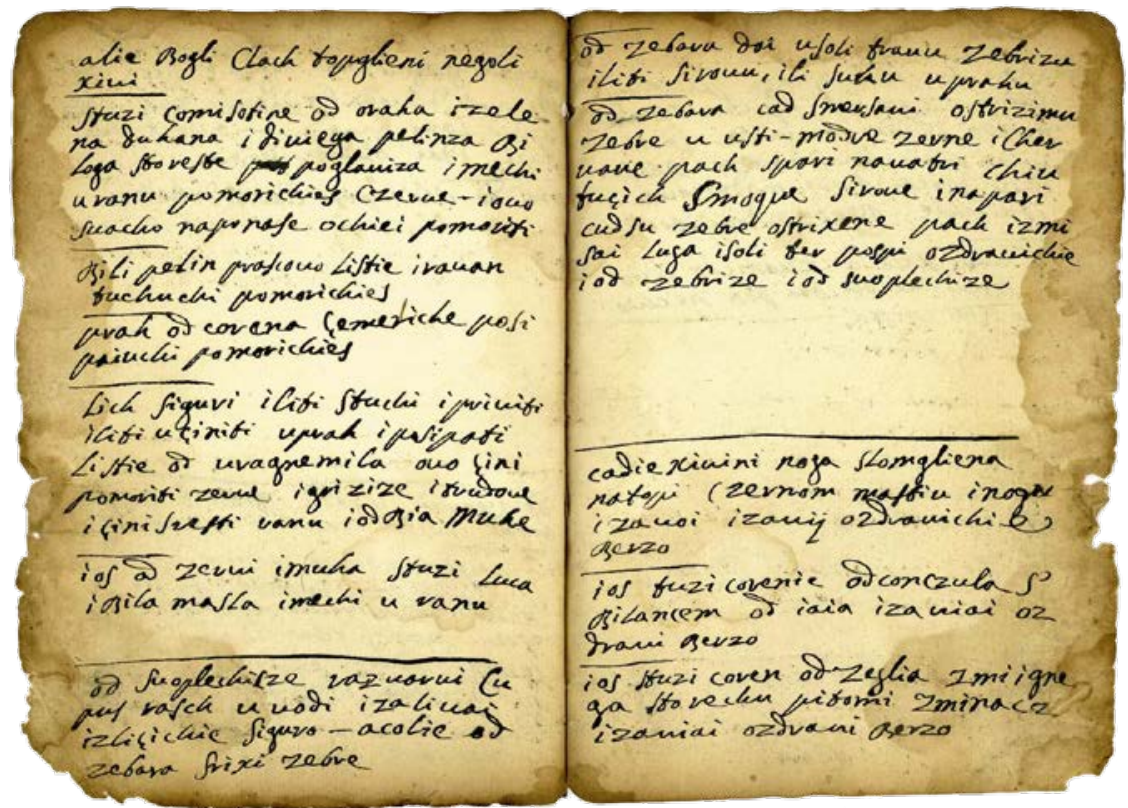

Slika I. Dvije od 288 stranica Velike poljičke (Bratulićeve) ljekaruše

je to neki korisnik naknadno učinio radi lakšeg snalaženja u velikom broju stranica. Tako je na vrhu 2. str. hrvatskom ćirilicom napisano ccašal (kašalj); na 3., 4. i 6. str. istim je pismom napisano otrovi; na 8., 26., 28. i 30. str. zmia; IO. str. guine; i2. str. dalaci; I4. str. tišlna (tišnja); 24. str. zlatijna itd. U tekstu se mogu naći riječi ili cijele rečenice napisane na talijanskom ili latinskom jeziku, što upućuje na jezik izvornika iz kojih su recepti prevođeni. Katkad se mogu naći rečenice napisane na izvornom jeziku i u prijevodu. Tako na 6I. str. nalazimo naslov: Secreto primo napolitano per li cavali mortidi, iza čega slijedi prijevod: Secret parvi od napuglie za cogne samartne...

Izgovor starog "jata“ je ikavski: mlico, bilo, ditetu, miseza, çovichu (= čoviku), tilo, sime, civ, misto, zdila, promini, zvit.... Kao i u drugim ljekarušama, i ovdje susrećemo ekavizam koren.

\section{Grafija}

Najveće poteškoće pri čitanju rukopisa ljekaruše čini nedosljedna i neujednačena grafija. Nerijetko se za isti glas upotrebljavaju različiti znakovi ili se isti znak koristi za različite glasove. Katkad u istoj riječi za isti glas nalazimo dva različita znaka. 
Glas k piše kao c ili ch, a potkraj teksta kao k: mecanu, cost, caco, mlico, onaco, licaria, cripost, velica, cruh, xvacaiuchi (=žvakajući)... svacho, soch, struch, çovichu, prascha, cicach (=čičak)... korenie.

g piše kao gh, a samo rijetko kao g: mnoghi, ulogh, noghe, ocrughla, ... nogu...

h se najčešće izostavlja: sa(h)ranili, trbu(h)uu, pra(h).

Pojavljuje se i kao v: muva. U pojedinim slučajevima slovo h služi za oznaku duljine vokala koji se nalazi ispred njega: prahah, iaiah (=jajah), travah...

nj piše kao gn: odgne (=od nje), gnegova, gnezin, nacigna (=načinja), ogagn, dignizu, ggnili (=gnjili), gnoi (=njoj), pceligni, cocosigne (=kokošinje)...

glas š piše kao ss ili kao s: gladissina, çassom (=čašom) nissador, isussi (=isuši), ussi, missa (=miša, miješa), ssia (=šija), rassegliche (=rašeljke)... ios (=još), nevirues (=ne virueš), brasno, usi...

Vokalno r bilježi se kao ar i rjeđe kao er: parsi, tarbuh, darxati, sarce, smartnim, zarni (=crni), carpi, zarvi, ... zerquinom, cercavize (=crkavice), zerve, chervi (=krvi)...

lj se piše kao gl: casagl (=kašalj), vaglia, cucoglia (=kukolja), poglscoga... Samo rijetko palatalizacija glasa 1 nije označena: lupina (=ljupina, ljuska)...

Ponekad se duljina glasova označava udvajanjem: usii, zubbe, solli...

č se najčešće bilježi kao c sa sedijom (ç) ili, rjeđe, kao c: çiçca (=čička), çorbi, ças, çovichu, çagia (=čađa), çimavice,... pocele, vecer (I), cini, nacigna, cistoi (=čistoj), pceligni, pticiza...

glas c piše se kao z: stuzi, tuzi, zucra, miseza, sunzu, dignizu, oztu, zidi, cozlaza (=kozlaca), iglize, zvit...

glas ć piše se kao chi ili ch: vruchie, prianuchie, tuchi, purichia, chuchi (=kući). Za ć koristi se i ti: zvitiem, listia ...

ž se piše kao $x$, ali se može naći i kao s: darxati, xvacaiuchi (=žvakajući), moxgiani, xediu (=žeđu)... darsi (=drži), spusa (=spuža)...

j piše kao i: uiutru, iesti, franaçcoi, priviai, cistoi (=čistoj), zgrianoi, gnoi...

Rjeđe, $\mathbf{j}$ se piše kao $j$ osobito kada su $i$ i $j$ zajedno, pri čemu su im mjesta zamijenjena: ijda (=jida), uijde (=ujide), guijne (=gujine).

c se piše kao cz ili kao c: czucarom (=cukrom), czarvi (=crvi)... cosirice (=kosirice), metvica...

d se piše kao gi: tacogier, dogie, probugiue, igie, megiu, moxgiani; i kao g: poge, tacoger ili kao di: poradia, xediu... 
Dvoglas kv uvijek se piše kao qv: tique, boqvize, smoqve, zerquinom, rodaqua...

Suglasnička skupina št piše se kao schi: nataschie (=natašte), pischi (=pišti), sidischia (sidišta), puschiai (=puštaj)...

Prijedlozi se često spajaju s riječi iza njih: nacosti, zaparsi, uiutru, zacilu, pognima...

Prijedlog s (sa) piše se uvijek kao s' i spaja s riječi uz koju stoji: s'ugliem, s'cruhom, s'mlicom...

Slova b i $\mathbf{r}$ na početku riječi, bez obzira na kojem se mjestu u rečenici nalazi, pišu se velikim slovima.

U futuru se tvorna enklitika će spaja s infinitivom, pri čemu se nastavak -ti često gubi: pribolichie (priboliti će), ozdravichie (ozdraviti će), pustichie (pustiti će), poginutichie (poginuti će), pristachie (pristati će)... Slično je i s glagolima na -ći: izachichie (izaći će).

Slovo u često se oblikom ne razlikuje od slova v.

Primjer Recepta za lijeČenje žUtice sa 23. Stranici lJekARUŠE

„iscopai zarnoga tarna pacha Bacivsci zarnu coru nastarxi xute pacha vari $\mathrm{u}$ vodi doch uvre trechina pacha pij zatri dni poiednu çasu uiutru drugu po ruçku a trechiu po veceri vidichies dachies tiscom mocriti, i ozdravichies."

(iskopaj crnoga trna pak bacivši crnu koru nastruži žute pak vari u vodi dok uvre trećina pak pij za tri dana po jednu čašu ujutru, drugu iza ručka a treću iza večere vidjeti ćeš da ćeš jako mokriti, i ozdraviti ćeš)

\section{Materia medica u Velikoj poljičKoj (Bratulićevoj) LjeKaruši}

Tvari od kojih se izrađuju ljekoviti pripravci, a opisane su u ljekarušama, kao i u ranim farmakopejama ponajviše su biljnog i, u mnogo manjem opsegu, životinjskog i mineralnog podrijetla. Budući da su ljekaruše dijelom kompilacije različitih zbirki recepata za izradu lijekova (druge ljekaruše, farmakopeje i njihove preteče koje su dolazile pod različitim imenima kao što su Antidotarium, Ricettario, Codex), razumljivo je da je tako i u ovoj ljekaruši. Najčešće se upotrebljavaju pristupačne biljke i životinje koje se mogu naći u domaćinstvu ili bližoj okolici. Tvari koje se u farmaceutskom smislu mogu smatrati otapalima ili pomoćnim tvarima su one iste koje se mogu naći gotovo u svakoj kući: voda, vino, rakija, ulje, ocat, šećer i med. Kao masne podloge za izradu ljekovitih masti (pomasti), melema i sličnih pripravaka gotovo uvijek se koriste masnoće domaćih životinja. Velik broj biljnih vrsta koje se 
koriste u Velikoj poljičkoj (Bratulićevoj) ljekaruši, koriste se i u suvremenoj fitoterapiji za liječenje istih ili sličnih bolesti odnosno tegoba. ${ }^{62,63}$

\section{SAstojci biljnog Podrijetla (BILjKe I Biljne Droge)}

Većina sirovina za pripravu lijekova u receptima ove ljekaruše dijelovi su biljaka i biljne droge. Ponajviše je riječ o domaćem ljekovitom bilju. U pravilu su to korijen, list, žile, sjeme, cvijet, kora i sok. Prepoznavanje naziva u ljekaruši otežano je zbog neujednačenog korištenja grafema za pojedine glasove. Pri pripisivanju suvremenih naziva biljaka nazivima u tekstu ove ljekaruše, najviše pomažu djela Ivana Šugara (Hrvatski biljni imenoslov) ${ }^{64}$, ali i knjige Bohuslava Šuleka (Jugoslavenski imenik bilja) ${ }^{65}$ i Frana Kušana (Ljekovito i drugo korisno bilje ${ }^{66}$ te prije objavljene ljekaruše. Katkad i sam autor navodi latinski ili talijanski naziv biljke, ili detaljno opisuje samu biljnu vrstu, što olakšava atribuciju. Ukupno je spomenuto oko 370 biljnih vrsta, gotovo jednako kao u najvećoj do sada objavljenoj ljekaruši (Velika sinjska ljekaruša $\left.{ }^{6}\right)$. Među biljkama koje se najčešće spominju u receptima su: ruta (u 33 recepta), ječam (u $25 \mathrm{rp}$ ), bijeli luk (28), pelin (24), pšenica (r9), kopriva, koromač i rosopas (I8), bazga i sljez (17), sporiš i smokva (I5), kadulja, betonika, kapula, kostrič (I3).

\section{SASTOJCI ŽIVOTINJSKOG PODRIJETLA U RECEPTIMA LJEKARUŠE}

Za razliku od ljekovitih pripravaka biljnog podrijetla (vegetabilia), koji su se tijekom povijesti medicine/farmacije koristili neprekidno i potvrdu svoje vrijednosti dobivali u praksi, a poslije i znanstvenim metodama, zanimanje za lijekove koji su sadržavali sastojke životinjskog podrijetla (animalia) bilo je vrlo promjenjivo. U pojedinim fazama razvoja medicine bili su vrlo popularni, da bi povremeno bili zanemareni. Začuđuje da je veliko zanimanje za te droge ponovno zavladalo na početku novog vijeka. Načela na kojima se osnivala upotreba različitih životinja, njihovih organa, sekreta i ekskreta, nisu se mogla znanstveno potvrditi kao valjana pa nestaju iz uporabe krajem I9. stoljeća. Vjerovalo se da se slično liječi sličnim (similia similibus curatur) $)^{68}$ i da će bolest prijeći s čovjeka na životinju ili njezin dio ako se isti privije na oboljelo mjesto. Mnogo se koristila i tzv. nečisna (nečistna, nečista) terapija u

62 Grdinić, Vladimir; Kremer, Dario (2009). Ljekovito bilje i ljkekovite droge: farmakoterpijski, botanički i farmaceutski podaci, Zagreb, Hrvatska ljekarnička komora.

63 Kuštrak, Danica (2005). Farmakognozija - Fitoterapija, Zagreb; Golden marketing - Tehnička knjiga.

64 Šugar, Ivan (2008). Hrvatski biljni imenoslov, Zagreb; Matica hrvatska.

65 Šulek, Bohuslav (1879). Jugoslavenski imenik bilja, Zagreb; JAZU.

66 Kušan, Fran (1956). Ljekovito i drugo korisno bilje, Zagreb; Poljoprivredni nakladni zavod.

67 Kujundžić, Nikola (2014). Velika sinjska ljekaruša.

68 Grdinić, Vladimir (2001). Ilustrirana povijest farmakopeje, Zagreb; Medika, str. 186-188. 
kojoj se koristi životinjski urin i izmet. Zanimljivo je da je ova vrsta terapije u I7. i I8. stoljeću bila prilično popularna, što pokazuje tiskanje nekoliko izdanja tzv. Heilsame Dreck-Apotheke ${ }^{69}$.

U ovoj ljekaruši često se susreću droge životinjskog podrijetla. Najzastupljenije su: jaje, meso, krv, jetra, koža, dlake i loj različitih životinja, pijavice, kost od sipe. Iz skupine tvari koje spadaju u nečisnu terapiju najčešće se koriste izmet i urin različitih životinja. To donekle pokazuje da je Velika poljička (Bratulićeva) ljekaruša stara najmanje dvjesta godina.

\section{SASTOJCI MINERALNOG PODRIJETLA, SMOLE I SLIČNE TVARI U RECEPTIMA}

LJEKARUŠE

Sastojci mineralnog podrijetla u receptima ove ljekaruše mnogo su manje zastupljeni nego oni biljnog i životinjskog podrijetla. U sljedećem popisu naveli smo samo najzastupljenije sastavnice recepata koje su mineralnog podrijetla te smole i druge slične tvari. To su: alaun (alumen, kocelj, kalijev aluminijev sulfat $\mathrm{KAl}\left(\mathrm{SO}_{4}\right) \cdot 12 \mathrm{H}_{2} \mathrm{O}$ ); puščani prah, barut, (mješavina kalijevog nitrata $\mathrm{KNO}_{3}$, sumpora i ugljena); pepeo (lug,); čađa (ugljik); modra galica (modri kamen, bakrov(II) sulfat pentahidrat, $\mathrm{CuSO}_{4} \cdot \mathrm{H}_{2} \mathrm{O}$ ); nišador (amonijev klorid, salmijak, $\mathrm{NH}_{4} \mathrm{Cl}$ ); sol (kuhinjska sol, natrijev klorid, $\mathrm{NaCl}$ ); sumpor.

Od smola koriste se smola od jele, smreke i bora te tamjan (smola koja se dobiva od biljke Boswelia sacra) ${ }^{70}$. Tirijak, prastari lijek protiv svih bolesti vrlo složenog sastava, nalazi se u i6 recepata.

\section{POMOĆNE TVARI}

Sastavnice recepata koje se u farmaceutskom smislu mogu smatrati pomoćnim, a ne djelatnim tvarima (otapala, masne podloge, korigensi okusa i mirisa i dr.) su: voda, vino, rakija, ocat, ulje, vosak, šećer i maslac, životinjske masnoće, alkohol, med i mlijeko. Te su tvari lako dostupne jer se koriste u domaćinstvu, a nalazimo ih u vrlo velikom broju recepata.

\section{Podrijetlo Recepata u Velikoj POljičKoj (BratulićEVoj) LJEKARUŠI}

Izvori iz kojih su recepti u ljekarušama uzimani, vrlo su raznoliki. Recepti su prepisivani iz drugih ljekaruša i knjiga sličnog sadržaja, pri čemu su često prevođeni s drugih jezika, najčešće s talijanskog i latinskog. Korištene su stare knjige lijekova, a od ı6. stoljeća i službene farmakopeje. Gotovo uvijek neki recepti u ljekarušama potječu iz narodne medicine. U ljekarušama se izvori

69 Isto, 192-194.

70 Hofman, Josip (1954). Synonima pharmaceutica, Zagreb; Farmaceutsko društvo Hrvatske. 
rijetko navode. S obzirom na opseg Velike poljičke (Bratulićeve) ljekaruše, broj navedenih izvora je mali. Spominju se Qvercetan (= Josephus Qquercetanus, dvorski liječnik kralja Henrika IV.), Galen, Avicena, Dioskurid, knjiga Herbario nuovo di Castore Durante, Venecija 1717. i neki drugi. Detaljniji uvid u podrijetlo recepata ove ljekaruše zahtijevao bi usporedbu velikog broja izvora, što prelazi okvire ovoga rada.

\section{MJeRE KOJE SE SPOMINJU PRI IZR ADI I UPORABI LIJEKOVA}

Osim znanja o djelotvornosti i umijeća izrade ljekovitih pripravaka, iznimno je važno doziranje jer svaki lijek može biti i otrov. Zbog toga su mjerenje i vaganje oduvijek bili nezaobilazni postupci pri pripremi i uporabi lijekova. U receptima drugih ljekaruša, a tako je i u ovoj, koriste se dvije vrste mjera. U receptima koji potječu iz neke od starih farmakopeja, odnosno knjiga koje su im prethodile, mjere koje se koriste su dram, libra, librica, litra i oka. U hrvatskim krajevima koji su bili pod vlašću Austrije, Venecije i Turske, sustav mjera bio je sve do Ig. stoljeća neujednačen. Svaki kraj imao je svoje mjere, a katkad su mjere imale isto ime, a različitu veličinu. Primjerice, venecijanska libra za lijekove težila zor g odnosno I2 unci, a austrijska je libra istodobno težila $420 \mathrm{~g}^{71}$.

U mnogim receptima rabe se približne i slabo definirane mjere koje su obično prikazane opisno: čaša, čašica, koliko može stati na određeni novčić, rukovet, šaka, zrno. U najvećem broju recepata mjere se uopće ne spominju. Sve je prepuštano iskustvu onoga tko lijek pripravlja.

U ovoj ljekaruši najčešće se susreću dram i unca.

\section{SAVJETI ZA DOMAĆINSTVO}

Ljekaruše u pravilu sadrže savjete za domaćinstvo. Najčešće je riječ o preporukama za konzerviranje hrane, čuvanje vina od kvarenja, usjeva od štetočina, kućanstva od insekata, zmija i dr. U ovoj ljekaruši, međutim, gotovo da nema ove vrste savjeta. $U$ jednom receptu preporučuje se što učiniti kada je u kući zmija (cadai u cuchi zmia).

BOLESTI (SIMPTOMI, TEGOBE) U RECEPTIMA LJEKARUŠE

Nazive bolesti, simptoma, patoloških stanja i zdravstvenih tegoba koje nalazimo u receptima ljekaruša najčešće nije moguće jednoznačno pripisati određenom dijagnostičkom entitetu kako ga definira suvremena medicina, pa to ostaje jedan od najvećih izazova pri proučavanju ovih vrijednih

71 Tartalja, Hrvoje (1963). O kemijskoj djelatnosti kod Južnih Slavena do XVIII stoljeća. Rasprave i građa za povijest nauka. Knjiga I. Zagreb; JAZU, 13. 
rukopisa. Ipak, u nekoliko ljekaruša koje su obrađene i objavljene u posljednjih desetak godina nalazimo pokušaje da se bolesti grupiraju prema Desetoj medunarodnoj klasifikaciji bolesti i srodnih zdravstvenih stanja (MKB-Io) ${ }^{72}$. Takav pristup prvi je prihvatio A. Škrobonja za Libar od likarij don Petra Kaštelana ${ }^{73}$, a poslije nastavio i N. Kujundžić pri obradi drugih ljekaruša. ${ }^{74,75} \mathrm{I}$ u ovoj ljekaruši medicinsko je nazivlje veoma bogato. Znatan je broj termina zaboravljen te je zanimljiv is jezičnog i s povijesnomedicinskog stajališta.

Navest ćemo samo bolesti koje se spominju u većem broju recepata: groznica (vrućica, fibra, malarija); guba (lepra); gliste (gujavice, ascaris lumbricoides, crvi); kuga; kolera; vrbanac;; svrab (scabies, šuga, svrabež); žutica (ikterus); antraks (travnjača, crni prišt); apostema (potkožnjak, gnojnica, micina); glavobolja; bolesti ušiju; bolesti grla; bolesti probavnog sustava; bolesti zubi; različite kožne bolesti (majasil = bolest pucanja kože na dlanovima i stopalima, lišajevi, maće, čirevi). Vrlo velik broj recepata posvećen je ranama te otrovanjima.

\section{Bolesti životinja}

Znatan broj recepata posvećen je liječenju bolesti domaćih životinja, najviše konja i goveda.

\section{ZAKLJUČAK}

Velika poljička (Bratulićeva) ljekaruša sadrži više od ııoo recepata i druga je po veličini do sada opisana ljekaruša. Ovdje smo prvi put predstavili osnovne značajke ove ljekaruše: opis rukopisa, tvari od kojih se lijekovi prave, među kojima prevladavaju one biljnog podrijetla, jezik te bolesti koje su tretirane. Bogat je izvor građe za proučavanje tradicionalne medicine, običaja, jezika, narodne predaje i općenito života u uvjetima poljičke samouprave u I8. stoljeću poznate kao Poljička republika. Velik broj ljekaruša koje potječu s prostora Poljica, kao i učestala upotreba hrvatske ćirilice koja ima posebna obilježja (poljičica), svakako su povezani s potrebom očuvanja posebnosti načina života i razmjerno visokog stupnja autonomije. Za podrobniji uvid u sadržaj ovog rukopisa u kontekstu vremena i društvenog okružja u kojem je upotrebljavan kao medicinski priručnik, potreban je multidisciplinarni pristup.

72 SZO (1994). Medunarodne klasifikacije bolesti i srodnih zdravstvenih stanja. Deseta revizija, Zagreb; Medicinska naklada.

73 Kujundžić, Nikola et al. (2011), Libar od likarij.

74 Kujundžić, Nikola (2014). Velika sinjska ljekaruša.

75 Kujundžić, Nikola (2017), 6. 


\section{LITERATURA}

1. Barnes, Joanne; Anderson, Linda A.; Phillipson, David J. (2002). Herbal Medicines, A guide for healthcare professionals, $2^{\text {nd }}$ Ed., London; Pharmaceutical Press.

2. Bartulović, Petar (1779). Razlicite likarie, Venecija.

3. Belicza, Biserka (1986), Pučka medicina u okolici Imotskoga prema zapisima fra Silvestra Kutleše, Kačić, 18, 78.

4. Berić, Dušan (1957), "Likarice" don Mikule Bobetića iz druge polovine XVII vijeka. Narodno zdravlje, 13, 386.

5. Boranić, Dragutin (1915), Đakovačka ljekaruša, Zbornik za narodni život i običaje Južnih Slavena, 20 (1), 142.

6. Brenko, Aida; Dugac, Željko; Randić, Mirjana (2001). Narodna medicina. Zagreb; Etnografski muzej.

7. Dürrigl, Marija A.; Fatović-Ferenčić, Stella (1995). Odabrani zapisi protiv bolesti u hrvatskim glagoljskim rukopisima. Liječnički vjesnik, (117), 152.

8. Dürrigl, Marija A.; Fatović-Ferenčić, Stella (1997), Marginalia medica croatico-glagolitica, Liječnički vjesnik, (119), 174.

9. Dürrigl, Marija A.; Fatović-Ferenčić, Stella (1999). Marginallia miscellanea medica in Croatian Glagolitic Monuments: a Model for Interdisciplinary Investigations, Viator, (30), 383.

10. Dürrigl, Marija A.; Fatović-Ferenčić, Stella (2009), Hrvatske ljekaruše između medicine, vjere i književnosti, u: Rasprave i građa za povijest znanosti, Knjiga 5, Razred za medicinske znanosti, Svezak 5, Zagreb, HAZU, 141.

11. Elazar, Samuel; Omanić, Ajnija (1984). Bibliografija medicinskih djela u SR BiH do 1895, Beograd-Zagreb; Medicinska knjiga.

12. Filipović-Fabijanić, Radmila (1971), "Domaći ljekar” iz 1868, godine sa Širokog Brijega, Glasnik Zemaljskog muzeja Bosne i Hercegovine; Etnologija; Nova serija, 26.

13. Fortis, Alberto (1984). Put po Dalmaciji, Zagreb; Globus, 205.

14. Grdinić, Vladimir (2001). Ilustrirana povijest farmakopeje, Zagreb; Medika.

15. Grdinić, Vladimir; Kremer, Dario (2009). Ljekovito bilje i ljkekovite droge: farmakoterpijski, botanički i farmaceutski podaci, Zagreb, Hrvatska ljekarnička komora.

16. Grmek, Mirko D. (1963). Rukovet starih medicinskih, matematičko-fizičkih, astronomskih, kemijskih $i$ prirodoslovnih rukopisa sačuvanih u Hrvatskoj $i$ Sloveniji. Rasprave i građa za povijest nauka. Knjiga I, Zagreb; JAZU, 259.

17. Gundrum-Oriovčanin, Fran (1909), Luićeva ljekaruša, Zbornik za narodni život $i$ običaje Južnih Slavena, 14 (1), 55.

18. Hofman, Josip (1954). Synonima pharmaceutica, Zagreb; Farmaceutsko društvo Hrvatske.

19. Ivanišević, Frano (2006). Poljica, Narodni život i običaji, Priko; Društvo Poljičana „Sveti Jure“, 296.

20. Kujundžić, Nikola (2014). Velika sinjska ljekaruša, Zagreb; Hrvatska akademija znanosti i umjetnosti, Matica hrvatska, Sveučilište u Zagrebu - Farmaceutskobiokemijski fakultet. 
21. Kujundžić, Nikola (2017), Ljekaruša fra Mirka Šestića. Obrada, transkript i faksimil, u: Rasprave i građa za povijest znanosti. Narodna medicina - izvori i straživanja; Zagreb, HAZU, (17), 6.

22. Kujundžić, Nikola; Glibota, Milan; Bival, Maja (2006), Ljekaruša fra Dobroslava Božića, Farmaceutski glasnik, 62 (12), 669.

23. Kujundžić, Nikola; Matasić, Vlatka; Glibota, Milan (2003), Ljekaruša fra Karla (Dragutina) Grančića, Farmaceutski glasnik, 59 (7-8), 321.

24. Kujundžić, Nikola; Škrobonja, Ante; Glibota Milan; Gašparac Petra (2011). Libar od likarij don Petra Kaštelana. Biblioteka AMHA, Prilozi povijesti zdravstvene kulture, Knjiga 7, Rijeka; Hrvatsko znanstveno društvo za povijest zdravstvene kulture i Medicinski fakultet Sveučilišta u Rijeci.

25. Kujundžić, Nikola; Škrobonja, Ante; Tomić Tomislava (2006), Plehanska ljekaruša „Zbirka lijekova sa zbirkom ljekovitih trava i uputom za pravit meleme i murćefe, Acta med-hist Adriat, 4 (1), 37.

26. Kujundžić, Nikola; Zorc, Marina; Glibota, Milan; Kujundžić, Milan (2004); Ljekaruša fra Jakova Bartulovića, Farmaceutski glasnik, 60 (11), 541.

27. Kušan, Fran (1956). Ljekovito i drugo korisno bilje, Zagreb; Poljoprivredni nakladni zavod.

28. Kuštrak, Danica (2005). Farmakognozija - Fitoterapija, Zagreb; Golden marketing - Tehnička knjiga.

29. Lalić, Josip (1849). Otvoranje domaćeg lečstva za ljude i marvu. Zagreb; Tiskom bratje Županah 1849.

30. Medić, Mojo (1909), Četiri ljekaruše, Zbornik za narodni život i običaje Južnih Slavena, 14 (2), 168.

31. Medić, Mojo (1904), Tri ljekaruše, Glasnik zemaljskog muzeja BiH, 16, 1 i 195.

32. Medić, Mojo (1909), Četvrta ljekaruša, Zbornik za narodni život i običaje Južnih Slavena, 14 (2), 253.

33. Milčetić, Ivan (1913), Stari glagoljski egzorcizmi, recepti i zapisi, Vjesnik Staroslavenske akademije, 13 (1), 61.

34. Nazor, Ante (2010). Knjige od likarije. Faksimil i obrada dviju ljekaruša pisanih hrvatskom ćirilicom. Rasprave i građa za povijest znanosti, Knjiga 10. Razred za medicinske znanosti, Svezak 6. Zagreb, HAZU.

35. Nazor, Ante Ml. (2010), Povijesni osvrt na Poljica, u: Knjige od likarije. Rasprave i građa za povijest znanosti. Knjiga 10. Zagreb; HAZU, 223.

36. Petter, Franz (1856). Dalmatien in seinen verschiedenen Bezichungen. Wien; Druck von Leopold Sommer, 198.

37. Poljak, Željko (1999), Odiseja jedne ljekaruše, Liječničke novine. (146), 42.

38. Poljak, Željko (2009). Karlobaške ljekaruše iz 1603. i 1707. godine, Faksimil i obrada, Rasprave i građa za povijest znanosti, Knjiga 9, Razred za medicinske znanosti, Svezak 5, Zagreb, HAZU.

39. Radić, Antun (1897). Osnova za sabiranje i proučavanje građe o narodnom životu, Zagreb; Zbornik za narodni život i običaje Južnih Slavena. Knjiga 2. 
40. Rimac-Lasić, Smilja; Škrobonja, Ante (1992), Tri ljekaruše imotskih franjevaca, Acta Fac ned flum, 17 (3-4), 183.

41. Romano, Jaša (1973). Jugoslovenska bibliografija lekaruša i narodnih medicinskih rukopisa. Beograd; Naučno društvo za istoriju zdravstvene kulture Jugoslavije.

42. Stojković, Marijan (1938), Dvije hrvatske ljekaruše iz Dalmacije, Zbornik za narodni život i običaje Južnih Slavena, 31 (2), 201.

43. Stošić, Krsto (1934), Šibenska ljekaruša, Liječnički vjesnik, 7, 189.

44. Strohal, Rudolf (1910), Folkloristički prilozi iz starije hrvatske knjige. I. Različiti zapisi i čaranja. (Glagoljski hrv. Spomenik iz 15. vijeka). Zbornik za narodni život $i$ običaje južnih Slavena, 15, 121.

45. Šugar, Ivan (2008). Hrvatski biljni imenoslov, Zagreb; Matica hrvatska.

46. Šulek, Bohuslav (1879). Jugoslavenski imenik bilja, Zagreb; JAZU.

47. Šušnić-Fliker, Zdenka (1986), Narodne ljekaruše iz Hrvatske nastale u XVII i XVIII stoljeću, Farmaceutski glasnik 42 (12), 367.

48. SZO (1994). Medunarodne klasifikacije bolesti i srodnih zdravstvenih stanja. Deseta revizija, Zagreb; Medicinska naklada.

49. Tartalja, Hrvoje (1963). O kemijskoj djelatnosti kod Južnih Slavena do XVIII stoljeća. Rasprave i građa za povijest nauka. Knjiga I. Zagreb; JAZU,13.

50. Tartalja, Hrvoje (1964), Ljekaruša iz Mađareva, Zbornik za narodni život i običaje Južnih Slavena, 489.

51. Ujević, Ante (1973), Ljekaruša fra Šimuna Gudelja Imoćanina, Kačić, 5, 121.

52. Vladimirović, Luka (1775). Likarije priprostite, Mleci; (Pretisak, transkripcija i prilozi. Priredio: Devetak Z. Knjižnica zbornika „Kačić“, br. 34, Split - Zaostrog: Franjevačka provincija Presv. Otkupitelja, 1999).

53. Vrčić, Vjeko (1984). Ljekaruše biskupa fra Paške Vujčića, Nova et vetera, 1-2, 139.

54. Zrnić, Lidija (2014). Jurićeva likaruša, Biblioteka AMHA, Prilozi povijesti zdravstvene kulture, Knjiga 10, Rijeka; Hrvatsko znanstveno društvo za povijest zdravstvene kulture i Medicinski fakultet Sveučilišta u Rijeci.

\section{SUMMARY}

The paper presents a folk recipe collection manuscript written by an unknown author in Poljica area, in the $18^{\text {th }}$ century. It is owned by the philologist, historian of literature and bibliophile, Josip Bratulic. Therefore, the author suggests that this recipe collection should bear the name Great folk medicine book from Poljica (Bratulic's folk medicine book). The manuscript is written in Latin script and Croatian language. It consists of 288 pages written in black ink and contains more than I,IOO recipes making it one of the largest known manuscripts. Although well preserved, a small part of it is unreadable. Most recommended recipes are for treating humans and domestic animals, while several recipes contain household tips. The abundance of its content, expressions, and healing instructions add this recipe collection to other similar manuscripts of this region, which create precious part of the Croatian medical, pharmaceutical, and cultural heritage.

Keywords: Bratulic's recipe collection, folk recipe collection, folk medicine, I $8^{\text {th }}$ century, Poljica, Croatia 